\title{
KAJIAN MORFOMETRIK DAN NISBAH JENIS KELAMIN IKAN LEMPUK (Gobiopterus sp) RANU GRATI, KABUPATEN PASURUAN, JAWA TIMUR
}

\section{MORPHOMETRIC DAN SEX RATIO OF LEMPUK FISH (Gobiopterus sp) IN RANU GRATI , PASURUAN DISTRICT, EAST JAVA}

\author{
Septi Anitasari*1, Abd Rahem Faqih ${ }^{2}$, Wahyu Endra Kusuma² dan Ating Yuniarti ${ }^{2}$ \\ ${ }^{1}$ Program Studi Manajemen Sumber Daya Perairan, Fakultas Perikanan dan Ilmu Kelautan, \\ Universitas Brawijaya, Jalan Veteran, Malang, Indonesia \\ ${ }^{2}$ Program Studi Budidaya Perairan, Fakultas Perikanan dan Ilmu Kelautan, Universitas \\ Brawijaya, Jalan Veteran, Malang, Indonesia \\ *email: septi.anitasari@ub.ac.id
}

\begin{abstract}
ABSTRAK
Ikan Lempuk (Gobiopterus $s p$ ) merupakan salah satu komoditas perikanan yang menjadi sumber kebutuhan protein hewani masyarakat serta daya tarik wisatawan yang berkunjung ke Ranu Grati Pasuruan Jawa Timur Indonesia. Ikan Lempuk (Gobiopterus sp) mudah ditemukan di Ranu Grati dan tidak ditemukan di tempat lain. Penelitian ini bertujuan untuk mengidentifikasi morfometrik dan nisbah jenis kelamin ikan lempuk (Gobiopterus $s p$ ). Hasil yang diperoleh dari penelitian ini adalah ikan Lempuk Ranu Grati termasuk dalam genus Gobiopterus. Morfologi ikan ini dapat dikenali dari warna tubuh transparan dimana organ dalam seperti jantung, pembuluh darah, tulang belakang ginjal, dan kantung renang dapat dilihat dari luar tubuh. Ikan ini memiliki panjang rata-rata $2,43 \mathrm{~cm}$, berat rata-rata 0,1223 gram. Bentuk badan fusiform, letak mulut sub terminal superior, bentuk sirip ekor truncate dengan tipe ekor diphycercal. Ikan ini memiliki gigi pada kedua rahang atau biasa disebut letak gigi vomer dan memiliki bentuk gigi canine, terdapat dua jenis bentuk ekor yaitu tipe Rounded dan Truncate. Nisbah jenis kelamin lebih dominan pada jantan daripada betina, dengan perbandingan 6,2: 3,8.
\end{abstract}

Kata kunci: Ikan Lempuk, Morfometrik, Nisbah jenis kelamin, Ranu Grati

\begin{abstract}
Lempuk Fish (Gobiopterus $s p$ ) is a fishery commodity as a source of the people's animal protein needs and is one of the attractions for tourists visiting Ranu Grati, Pasuruan, East Java Indonesia. The purpose of this study was to identification the morphometrics and sex ratio of Lempuk fish (Gobiopterus sp). Lempuk fish (Gobiopterus $s p$ ) is easy to find in Ranu Grati and not found anywhere else. The results obtained from this study are the grati ranu lempuk fish belonging to the genus Gobiopterus sp. The morphology of this fish and can be recognized by its transparent body color where internal organs such as the heart, kidneys, swim bladder, blood vessels and spine can be seen from outside the body. This fish has an average length of 2.43 $\mathrm{cm}$, an average weight of 0.1223 grams. Fusiform body shape, mouth location of superior subterminal, truncate tail fin shape with diphycercal tail type. This fish has teeth on both jaws or commonly known as vomer teeth and has a canine tooth shape, found two types of tail shapes, namely the Rounded and Truncate types. The sex ratio is more dominant for males than females at $6.2: 3.8$.
\end{abstract}

Keywords: Morphometric, Lempuk fish, Ranu Grati, Sex ratio 


\section{PENDAHULUAN}

Indonesia merupakan salah satu negara dengan keanekaragaman hayati fauna yang sangat tinggi. Keanekaragaman hayati fauna tersebut antara lain berbagai jenis ikan lokal. Indonesia. Syafei dan Sudinno (2018) menyebutkan bahwa Indonesia tercatat sebagai negara dengan megabiodiversitas nomer tiga di dunia dan mempunyai 1.193 spesies ikan, yang mana 120 merupakan spesies endemik. Indonesia memiliki ikan endemik dan beberapa jenis spesies ikan lokal yang mempunyai ciri tubuh yang berbeda-beda. Luasnya wilayah Indonesia menjadikan Indonesia mempunyai beragam ikan lokal. Spesies Ikan lokal mengacu kepada ikan yang banyak disukai masyarakat untuk dijadikan sebagau ikan konsumsi (Budiharjo, 2002).

Kelompok ikan yang memiliki potensi ekonomi tinggi sebagai ikan konsumsi khususnya di Ranu Grati salah satunya adalah ikan dari genus Gobiopterus yang merupakan asli Ranu Grati dengan ukuran tubuh 2-3 cm. Ranu Grati merupakan sebuah danau vulkanik yang terbentuk akibat letusan gunung berapi.

Untuk menjaga dan melestarikan keanekaragaman kekayaan plasma nutfah yang ada, maka perlu dilakukan identifikasi morfometrik dan mengetahui perbandingan jenis kelamin ikan Lempuk (Gobiopterus sp) Ranu Grati, kabupaten Pasuruan Jawa Timur.

\section{METODOLOGI}

\section{Lokasi pengambilan sampel}

Pengumpulan spesimen dilakukan di 5 stasiun di Ranu Grati, kecamatan Grati, kabupaten Pasuruan Jawa Timur, Indonesia (743'28.8" S: $113^{\circ} 46.4^{\prime \prime}$ T). Pengambilan dan koleksi sampel dilakukan menggunakan rumpon yang kemudian diambil dari jaring yang terpasang menggunakan seser. Penentuan titik pengambilan sampel didasarkan pada penempatan rumpon yang ada di danau karena diperkirakan pada musim kemarau ikan lempuk cenderung berada di tengah. Karakter lokasi pengambilan sampel disesuaikan juga dengan karakter habitat alami ikan lempuk yang umumnya hidup di dekat atau bagian dasar danau serta beberapa aliran sungai yang tidak terlalu deras (Kottelatt, 2013).

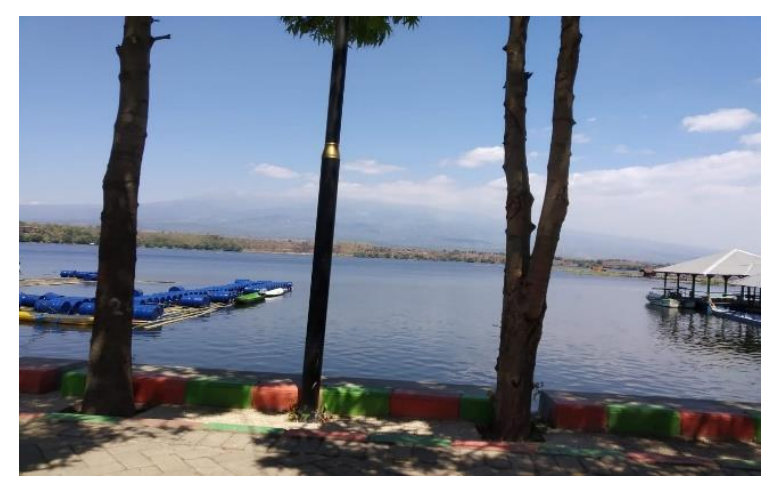

Gambar 1. Ranu Grati, lokasi pengumpulan sampel

\section{Koleksi Sampel}

Proses pengambilan sampel untuk koleksi spesimen diperoleh dengan menggunakan jaring tarik dan jaring scoop dengan ukuran mata jaring $0,5 \mathrm{~cm}$. Sebanyak 50 lempuk dikumpulkan dari Ranu Grati. Ikan dikumpulkan dengan hati-hati untuk mencegah kerusakan pada spesimen. Pengumpulan data jumlah spesimen disertai dengan identifikasi jenis yang cepat dan sederhana, baik dengan instrumen maupun observasi langsung. Pengambilan sampel ikan Pengambilan sampel dilakukan tanpa izin khusus, namun warga sekitar melarang penggunaan alat yang tidak bersahabat (Hasan et. al, 2020).

Bahan yang digunakan antara lain adalah ikan Lempuk (Gobiopterus $s p$ ) sebagai sampel uji, serta formalin dengan konsentrasi $10 \%$ untuk mengawetkan sampel dan alat yang digunakan antara lain Timbangan 0 Haus dengan ketelitian 0,1 (g), Styrofoam, Pena, Penggaris ukuran 30 $\mathrm{cm} /$ jangka sorong, Kertas Label, Kamera Digital, jarring dan rumpo.

\section{HASIL DAN PEMBAHASAN}

\section{Ekologi Perairan Ranu Grati}

Ranu Grati merupakan sebuah danau vulkanik yang terletak $16 \mathrm{~km}$ arah timur Kota Pasuruan, Provinsi Jawa Timur. Ranu 
Grati berada di Desa Ranu Klindungan, Kecamatan Grati, Kabupaten Pasuruan. Luas wilayah sekitar 198 hektar, dan berada di daerah dataran rendah. Ranu Grati berada pada ketinggian antara 6-91 mdpl. Ikan Lempuk (Gobiopterus sp.) adalah salah satu ikan lokal Ranu Grati. Populasi ikan Lempuk (Gobiopterus sp.) tersebar luas di tengah danau. Secara ekologis ikan lempuk (Gobiopterus sp.) memiliki peranan penting pada struktur tingktatan trofik di Ranu Grati. Ikan lempuk (Gobiopterus sp.) berperan sebagai konsumen tingkat pertama dan organisme planktonik utama yang mendukung keberadaan organisme konsumen pada tingkatan trofik berikutnya di Ranu Grati. Kondisi kualitas air di Ranu Grati, Kabupaten Pasuruan sebagai berikut: Parameter kualitas air (biologi) plankton di kawasan ikan lempuk (Gobiopterus sp.) Ada 2 jenis, yaitu fitoplankton dan zooplankton. pada fitoplanton antara lain Chlorophyta dan Chrysophyta. Zooplankton di Ranu Grati terdiri dari filum Protozoa, filum Arthropoda, serta filum Rotifera. Kualitas air (Fisika serta Kimia) di lokasi ikan Lempuk (Gobiopterus sp.) didapatkan hasil rata-rata : suhu $29-31{ }^{\circ} \mathrm{C}$, , $\mathrm{pH}$ normal kisaran 7, DO 2,82-6,10 mg/l, kecerahan berkisar 56,25 - 80,5 cm, CO2 5,9 - 13,9 $\mathrm{mg} / \mathrm{l}$, serta nilai TOM 10,16-20,12 mg/l (Rukmana et. al, 2015).

\section{Morfologi}

Ikan lempuk di Ranu Grati adalah salah satu genus Gobiopterus yang belum teridentifikasi secara pasti spesiesnya. Gambar di bawah menunjukkan ikan lempuk (Gobiopterus sp.) di Ranu Grati.

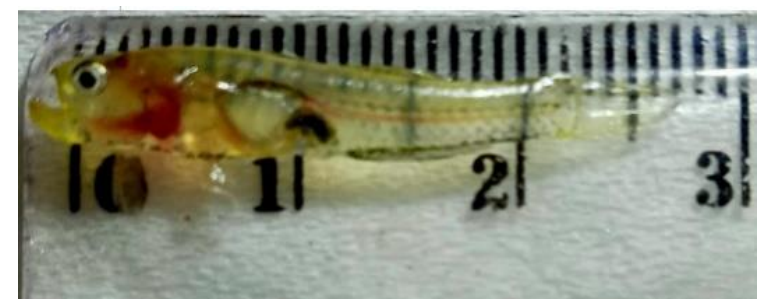

Gambar 2: Ikan Lempuk (Gobiopterus sp) panjang total: $2,9 \mathrm{~cm}$

Dari Gambar 2 dapat diamati secara morfologi, ikan Lempuk (Gobiopterus sp.) dapat dikenali dari warna tubuh transparan sehingga organ dalam seperti pembuluh darah, jantung, ginjal, tulang belakang dan gelembung renang dapat terlihat dari luar tubuh. Dan keadaan ini seperti yang dikemukakan oleh Imam (2011) bahwa ikan lempuk transparan dan bagian dalam tubuhnya dapat dilihat dari luar seperti ginjal, jantung, gelembung renang dan organ lain sebagainya. Ikan lempuk (Gobiobterus sp.) merupakan salah satu ikan lokal danau Ranu Grati yang mirip dengan ikan teri yang mempunyai ukuran 2-3 cm. Ikan Lempuk (Gobiopterus sp.) juga berbentuk transparan, dan yang terlihat hanya mata dan organ dalam. Ikan lempuk berkembang biak secara alami tanpa campur tangan manusia, dan secara umum siklus perkembangbiakannya setiap 4 bulan (Bramestian, et al., 2016). Lebih lanjut menurut Imam, et al. (2011), karakter morfologi Gobiopterus sp antara lain kepala cenderung pendek dan lebar dengan moncong bulat. Mempunyai gigi relatif kecil dan runcing dengan bentuk kerucut. Patzner, et. al. (2011), menyatakan bahwa secara umum spesies ikan lempuk (Gobiopterus $s p$ ) ditandai dengan tubuh transparan dengan pigmen hitam atau coklat. Selain dari Jawa dan Papua Barat, terdapat ikan jenis dar genus Gobiopterus dengan berukuran mungil dan transparan seperti ikan Lempuk di Danau Ranu Grati kabupaten Pasuruan (Hadiaty, et al., 2012). Selain itu spesies ini juga memiliki saluran pencernaan yang pendek dan lurus.

\section{Morfometrik Ikan Lempuk}

Berdasarkan hasil pengamatan pada ikan Lempuk (Gobiopterus sp) dapat dijelaskan bahwa ikan ini mempunyai bentuk tubuh fusiform (Gambar 1), lokasi mulut sub terminal superior (Gambar 6), bentuk sirip ekor truncate dengan tipe ekor diphycercal (Gambar 3 dan 4). Letak sirip perut/pelvic (V) terhadap sirip dada/pectoral (P) adalah Thoracic (letak sirip perut persis di bawah sirip dada), sirip punggung/dorsal (D) bertipe ganda, mempunyai sirip dada/pectoral fin, sirip perut/pelvic fin, sirip punggung/dorsal fin, sirip ekor/caudal fin 
dan sirip dubur/anal fin (lihat Gambar 1, 3 dan 4). Ikan lempuk (Gobiopterus sp.) memiliki sisik berbentuk stenoid, dimana sisik stenoid merupakan sisik ikan yang kecil, tipis, sisik ikan yang ringan. Ikan lempuk (Gobiopterus sp.) memiliki gigi pada kedua rahangnya atau biasa disebut gigi lokasi vomer dan memiliki gigi canine. Berikut adalah gambar ikan lempuk (Gobiopterus sp.) yang diawetkan (Gambar 3 dan 4).

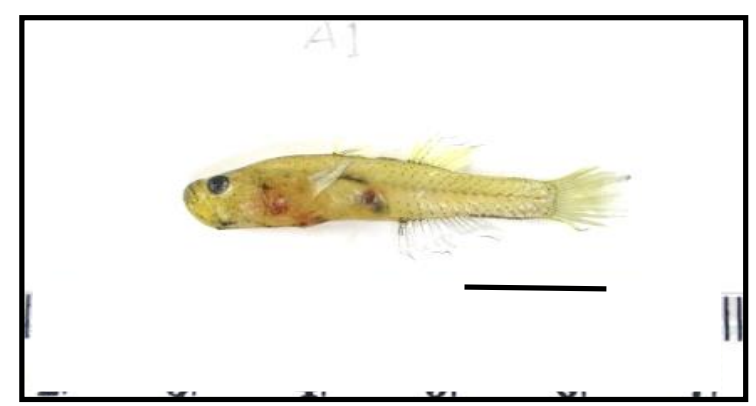

Gambar 3. Ikan Lempuk (Gobiopterus sp) dengan tipe ekor rounded

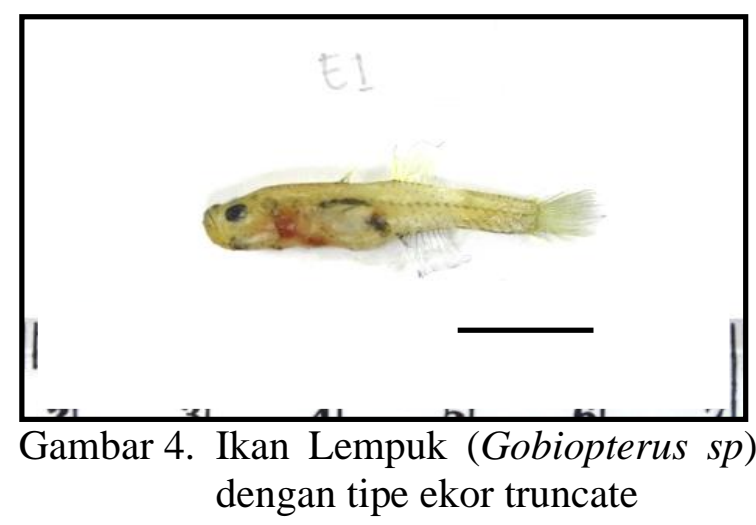

Ciri-ciri morfologi tersebut seperti yang digambarkan oleh Moyle dan Cech 1988) yakni bentuk tubuh fusiform, letak mulut sub terminal superior, bentuk sirip ekor truncate dengan tipe ekor diphicercal. posisi sirip perut $(\mathrm{V})$ terhadap sirip dada $(\mathrm{P})$ yaitu Thoracic (sirip perut perut terletak tepat dibawah sirip dada), tipe sirip punggung (D) yaitu ganda, terdapat sirip dada (Pectoral fin), perut (Pelvic fin), punggung (Dorsal fin), ekor (Caudal fin) dan dubur (anal fin).

Berikut ini diperlihatkan hasil pengamatan beberapa bagian morfologi ikan Lempuk (Gobiopterus sp) di Ranu Grati.

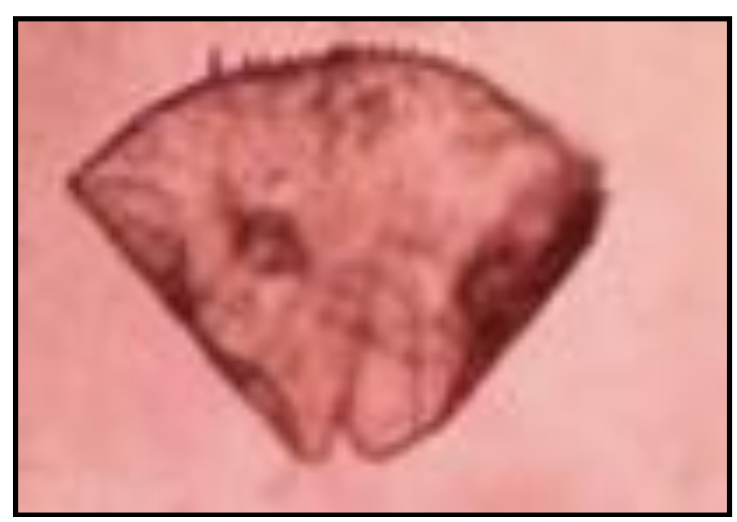

Gambar 5. Sisik ikan lempuk (Gobiopterus $s p$ ) berbentuk Stenoid

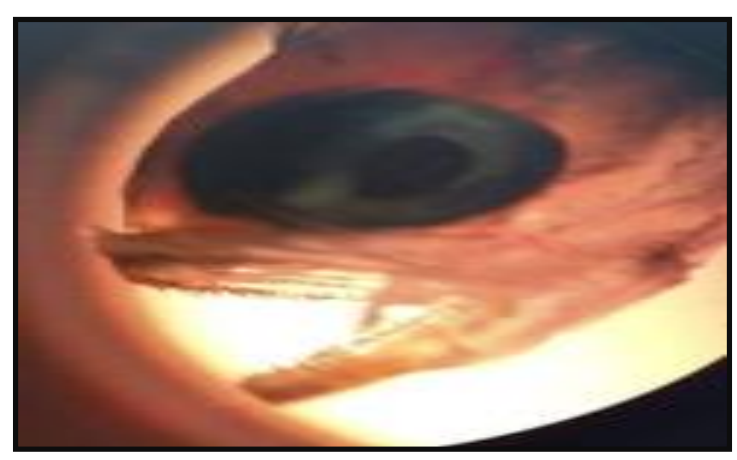

Gambar 6. Bentuk mulut ikan Lempuk (Gobiopterus sp)

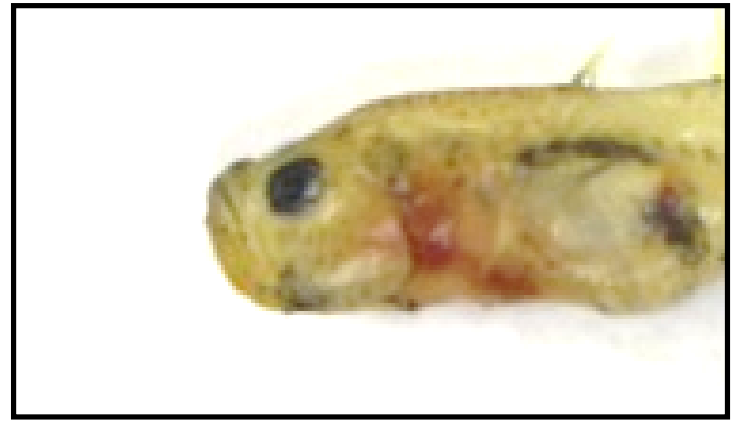

Gambar 7. Posisi mulut ikan Lempuk (Gobiopterus sp)

Hasil pengamatan di atas sesuai dengan apa yang dijelaskan oleh Moyle dan Cech (1988) Namun demikian pada hasil pengamatan ikan lempuk Ranu grati telah ditemukan dua tipe bentuk ekor yaitu tipe Rounded dan Truncate.

Sedangkan dimensi ukuran morfometrik bagian tubuh ikan lempuk (Gobiopterus sp) Ranu Grati ditunjukkan pada tabel 1 berikut ini. 
Tabel 1. Ukuran morfometrik Ikan Lempuk (Gobiopterus sp)

\begin{tabular}{|c|c|c|c|c|c|c|c|c|c|}
\hline Stasiun & Total & $\begin{array}{c}\text { Total } \\
\text { Length } \\
\end{array}$ & $\begin{array}{c}\text { Standard } \\
\text { Length }\end{array}$ & $\begin{array}{c}\text { Linea } \\
\text { Lateralis }\end{array}$ & $\begin{array}{c}\text { Kepala } \\
(\mathbf{c m})\end{array}$ & $\begin{array}{c}\text { Ekor } \\
(\mathbf{c m})\end{array}$ & $\begin{array}{c}\text { Berat } \\
\text { (gram) }\end{array}$ & \multicolumn{2}{|c|}{$\begin{array}{c}\text { Jenis } \\
\text { Kelamin }\end{array}$} \\
\hline $\mathbf{1}$ & 10 & 2.69 & 2.25 & 0.47 & 0.44 & 0.41 & 0.1224 & 6 & 4 \\
\hline $\mathbf{2}$ & 10 & 2.50 & 2.12 & 0.43 & 0.36 & 0.41 & 0.1286 & 6 & 4 \\
\hline $\mathbf{3}$ & 10 & 2.61 & 2.26 & 0.40 & 0.41 & 0.41 & 0.1245 & 6 & 4 \\
\hline $\mathbf{4}$ & 10 & 2.27 & 1.89 & 0.35 & 0.36 & 0.36 & 0.0954 & 6 & 4 \\
\hline $\mathbf{5}$ & 10 & 2.09 & 1.90 & 0.31 & 0.32 & 0.34 & 0.1434 & 7 & 3 \\
\hline Rerata & 10 & 2.43 & 2.08 & 0.39 & 0.38 & 0.38 & 0.1223 & 6.2 & 3.8 \\
\hline
\end{tabular}

Pada seluruh stasiun pengambilan sampel, didapatkan sampel sebanyak 50 ekor ikan lempuk. Berdasarkan hasil pengamatan pada keseluruhan stasiun pengambilan sampel dapat disampaikan bahwa rerata panjang total atau total length $2.43 \mathrm{~cm}$, rerata panjang baku atau standard length $2.35 \mathrm{~cm}$, untuk linea lateralis 0.39 $\mathrm{cm}$, Panjang kepala $0.38 \mathrm{~cm}$ dan Panjang ekor sebesar $0.38 \mathrm{~cm}$ dengan rerata berat sebesar 0.1223 gr. Sedangkan nisbah jenis kelamin antara jantan dan betina sebesar 6.2 : 3.8 .

Namun jika diamati masing-masing dimensi ukuran pada tiap stasiun pengambilan sampel dibandingkan dengan rerata ukuran pada keseluruhan stasiun dapat diperoleh gambaran sebagai berikut : Panjang total atau total length ikan pada stasiun pengambilan sampel 1 memiliki total length yang paling panjang $(2.69 \mathrm{~cm})$.

Kemudian diikuti oleh stasiun pengambilan sampel 3, dan 2, dan total length pada stasiun pengambilan sampel 1,2 dan 3 masih lebih panjang dibandingkan dengan ukuran rerata keseluruah ukuran total length. Sedangkan ukuran total length terkecil didapatkan pada stasiun pengambilan sampel 5, yang diikuti oleh stasiun pengambilan sampel 4 dan total length pada stasiun tersebut masih lebih kecil (pendek) dibandingkan ukuran rerata total length keseluruhan sampel.

Untuk pengamatan panjang baku atau standard length ukuran ikan lempuk tertinggi terdapat stasiun pengambilan sampel 1 kemudian diikuti oleh stasiun 3, 2 . Dan pada stasiun-stasiun tersebut ukuran standard length ikan lempuk masih lebih tinggi dibandingkan dengan rerata keseluruhan stasiun. Sedangkan ukuran standard length terkecil terdapat pada stasiun pengambilan sampel 4 selanjutnya diikuti stasiun 5. Dan kedua stasiun terakhir masih lebih kecil dibann dingkan dengan rerata ukuran keseluruhan stasiun pengambilan. Menurut Imam (2011), morfologi tubuh Gobiopterus sp. termasuk famili gobidae yang memiliki panjang standar (standard length) berkisar 2.6 -3.1 $\mathrm{cm}$.

Hasil pengamatan linea lateralis, ukuran tertinggi didapatkan pada stasiun 1, dan diikuti stasiun 2 dan 3 dimana stasiunstasiun tersebut masih lebih Panjang ukurannya dibandingkan rerata keseluruhan ukuran $(0.39 \mathrm{~cm})$. Sedangkan ukuran linea lateralis terpendek didapat pada stasiun 4 . Untuk ukuran linea lateralis terpendek didapat pada stasiun 5 dan jika dibandingkan dengan ukuran linea lateralis rerata keluruhan stasiun masih paling pendek.

Sementara untuk ukuran kepala dan ekor, ukuran tertinggi didapat pada stasiun 1 baik untuk ukuran kepala dan ekor bahkan kedua stasiun ini lebih besar ukurannya jika dibandingkan dengan ukuran rerata pada keseluruhan stasiun pengambilan sampel tersebut, sedangkan untuk ukuran terkecil didapatkan pada stasiun 5 baik untuk ukuran kepala maupun ekor dan bahkan jika dibandingkan dengan ukuran rerata keseluruhan stasiun pengambilan sampel masih lebih kecil ukuran stasiun pengambilan 5 dan 4 .

Adapun jika dilihat dari aspek berat ikan lempuk ranu grati dapat digambarkan sebagai berikut : berat ikan terberat terdapat 
pada stasiun pengambilan sampel $5(0.1434$ gr), yang selanjutnya diikuti oleh sampel ikan yang berasal dari stasiun 2 yaitu (0.1286 gr), stasiun 3 ( 0.1245 gr) dan stasiun 1 (0.1224 gr). Sedangkan berat terendah terdapat pada stasiun4 (0.0954 gr). Dan jika rerata masing-masing berat pada stasiun pengambilan sampel dibandingkan dengan rerata keseluruhan stasiun (0.2234 gram) ternyata masih lebih besar masing-masing stasiun sampling kecuali stasiun 4 lebih kecil

Hasil koleksi spesimen ikan lempuk Ranu Grati (Gobiopterus sp.) jika dibandingkan ikan $G$. brachypterus dan $G$. chuno sesuai dengan pendapat Imam (2010), bahwa terdapat dua tipe ikan Gobiopterus $s p$. di Ranu Grati. Tipe pertama yakni mempunyai karakteristik jari-jari sirip dorsal pertama (D1) 4-5, pada sirip dorsal kedua (D2) 1,7-1,8, 29. Pada jari-jari sirip anal (A)1,10-1,13, dengan tinggi badan 4,55 kali lebih pendek dibandingkan panjang standar (SL/standard length). Rerata standard length adalah $22 \mathrm{~mm}$, dan terdapat pigmen hitam di bagian dorsal midline serta terdapat pigmen hitam hitam vertikal di pipi dan pada batas preoperculum. Sedangkan ciri-ciri pada ikan Lempuk (Gobiopterus sp.) tipe kedua yaitu jari-jari sirip dorsal yang pertama (D1) 4-5 dan sirip dorsal kedua (D2) 1,7-1,9. Jari-jari sirip anal berjumlah (A)1,11-1,15 dengan tinggi badan 4,5-5 kali lebih pendek dibandingkan panjang standar (standard length). Rerata standard length yaitu $24 \mathrm{~mm}$, ditemukan pigmen hitam di bagian dorsal midline dan ditemukan juga pigmen hitam hitam vertikal di pipi serta batas preoperculum. pada ikan $G$. brachyopterus memiliki D1 sejumlah 5 dan D2 8, A sejumlah 11-12 dengan tinggi badan 6 kali lebih pendek dibandingkan standard length, mempunyai pigmen hitam vertikal pada pipi dan pre-operculum terdapat pigmen hitam pada midline dan rata-rata standard length $20 \mathrm{~mm}$. Ikan G. chuno mempunyai D1 sejumlah 5 dan D2 8-9, A sejumlah 10-11. Tinggi badan 4.5-5 kali lebih pendek dibandingkan standard length, dan tidak mempunyai pigmen hitam vertikal pada bagian pipi dan pre-operculum serta tidak ada pigmen hitam di midline serta rerata standard length $20 \mathrm{~mm}$.

Perbedaan karakter morfometrik dan meristik pada lempuk (Gobiopterus sp.) ini dapat disebabkan oleh faktor internal maupun eksternal. Faktor eksternal yang mempengaruhi antara lain lokasi ikan serta kualitas air, yang mana ikan yang diamatu diperoleh dari beberapa stasiun pengambilan sampel. Faktor internal yang mempengaruhi yaitu umur ikan dan jenis kelamin. Hal ini senada dengan pernyataan Putri, et al. (2015), perbedaan lingkungan dapat mempengaruhi perbedaan karakter morfometrik ikan di suatu perairan tawar. Perbedaan lingkungan yg dapat terjadi antara lain perbedaan $\mathrm{pH}$, suhu, kecerahan, oksigen terlarut dan kekeruhan. Kualitas air di perairan dapat berpengaruh pada karakter morfometrik ikan jantan dan betina di lokasi pengambilan sampel.

Berdasarkan

perbandingan kelamin ikan lempuk (Gobiopterus sp.) Ranu Grati didapatkan perbandingan 6.2 : 3.8. Dalam hal ini jenis kelamin jantan lebih dominan dari betinanya. Pengetahuan mengenai aspek biologi ikan yang hidup di perairan umum maupun yang dibudidayakan penting dalam manajemen dan konservasi sumberdaya perikanan (Djumanto, et al., 2012). Biologi reproduksi ikan salah satu diantaranya yaitu rasio jenis kelamin, ukuran pada kematangan gonad, musim pemijahan, fekunditas dan faktor kondisi spesies. Namun, juga dibutuhkan informasi biologis secara terperinci mengenai kelimpahan stok, reproduksi dan pertumbuhan spesies ini dari wilayah geografis mana pun dimana penyebarannya masih kurang sejauh ini untuk mendukung eksploitasi berkelanjutan (Ahamed, et al., 2018). Nisbah kelamin dapat diketahui dari bentuk fisik tubuh ikan yaitu Panjang dan tubuh ikan (Sari, 2016). Pertumbuhan ikan jantan diketahui lebih cepat dan lebih besar dari ikan betina. Menurut Bhatta, et al. (2012), hal itu berperan penting untuk menentukan sejauh mana karakter dimorfik yang menunjukkan kematangan gonad. Namun informasi 
tentang mengapa ukuran jantan lebih besar daripada betina masih perlu dikaji secara memadai.. Oleh karena itu, menjadi sangat relevan saat mempertimbangkan fakta bahwa pematangan seksual mungkin terkait berbagai ukuran dan perkembangan.

\section{KESIMPULAN DAN SARAN}

\section{Kesimpulan}

Berdasarkkan hasil pengamatan terhadap ikan lempuk (Gobiopterus sp.) di Ranu Grati disimpulkan bahwa ikan lempuk (Gobiopterus sp.) di Ranu Grati memiliki varisi ukuran pada masing-masing stasiun pengambilan sampel dan Nisbah jenis kelamin antara jantan dan betina, ternyata jantan lebih dominan dengan perbandingan $6.2: 3.8$.

\section{Saran}

Disarankan untuk melakukan
identifikasi secara molekuler untuk mengetahui lebih lanjut spesies ikan Lempuk (Gobiopterus sp) di Ranu Grati

\section{DAFTAR PUSTAKA}

Ahamed F, Saha N, Ahmed ZF, Hossain MY, Ohtomi J. Reproductive biology of Apocryptes bato (Gobiidae) in the Payra River, southern Bangladesh. Journal of Applied Ichthyology. 2018 Oct;34(5):1169-75.

Budiharjo, A. 2002. Seleksi dan potensi budidaya jenis-jenis ikan wader dari genus Rasbora. BIODIVERSITAS. 3(2): 225-230.

Bhatta, S., Iwai, T., Miura, C., Higuchi, M., Shimizu-Yamaguchi, S., Fukada, H. and Miura, T., 2012. Gonads directly regulate growth in teleosts. Proceedings of the National Academy of Sciences, 109(28), pp.11408-11412.

Bramestian, R. H. Budiarjo dan D. Y. Yurisma. 2016. Perancangan place identity ranu grati sebagai upaya untuk meningkatkan brandawareness.
Institut bisnis dan informatika stikom surabaya.1-8.

Djumanto, Eko S. Rudiansyah. 2012. Fekunditas ikan glodok, Beleophthalmus boddarti. Pallas, 1770, 59-71.

Hadiaty, R. K., Gerald R. Allen dan M.V. Erdmann. 2012. Keanekaragaman jenis ikan di Teluk Arguni, Kaimana, Papua Barat. Zoo Indonesia .21(2): 3542.

Hasan V, Widodo MS, Faqih AR, Mahasri G, Arief M, Valen FS, Tamam , MB, Yonarta D, Pratama FS, Fitriadi R. 2020b. Presence of striped flying barb Esomus metallicus (Teleostei, Cyprinidae) from West Sumatra, Indonesia. Ecol Environ Conserv 26: S73-S75.

Imam, Muhamad (2011) Variasi Morfologi pada Ikan Lempuk (Gobiopterus brachypterus) di Danau Ranugrati Pasuruan. Magister thesis, Universitas Brawijaya.

Kottelat M, Whitten AJ, Kartikasari SN \& Wiroatmodjo S. 1993. Freshwater Fishes of Western Indonesia and Sulawesi. Edisi Dwi Bahasa InggrisIndonesia. Periplus Edition (HK) Ltd. Bekerjasama dengan Kantor Menteri KLH, Jakarta, Indonesia.

Moyle PB \& Cech JJ. 1988. Fishes An Introduction to Ichthyology. Second Edition. Departemen of Wildlife and Fisheries Biology University of California, Davis. Prentice Hall, Englewood Cliffs, New Jersey 07632. p. $559: 309$ - 310.

Patzner, R., J. L. Van Tassell, M. Kovacic and B. G. Kapoor. 2011. The Biology of Gobies. CRC Press. USA. 702 p.

Putri, R. A., R. Elvyra dan Y. Yusfiati. 2015. Karakteristik morfometrik dan meristic ikan lais danau (Ompok 
Hypophthalmus Bleeker, 1846) di sungai tapung dan sungai siak. JOM FMIPA. 2(1): 57-66.

Rukmana, Dessy Nufikhasari .2015. Studi Ekologi Ikan Endemik Lempuk (Gobiopterus sp.) Di Ranu Grati Kecamatan Grati, Kabupaten
Pasuruan, Jawa Timur. Skripsi. Universitas Brawijaya.

Syafei, L. S., dan Sudinno, D. 2018. Ikan Asing Invasif, Tantangan keberlanjutan biodiversitas perairan. Jurnal Penyuluhan Perikanan dan Kelautan. 12(3): 149-165. 